\title{
Prevalence Reduction of Contagious Mastitis Pathogens in a Holstein Dairy Herd Under Tropical Conditions
}

\author{
Juliana FM Mendonça1, Maria AVP Brito ${ }^{2}$, Carla C Lange ${ }^{2,3}$, Márcio R Silva ${ }^{2,3}$, João B Ribeiro ${ }^{2,3}$, Letícia C Mendonça² and Guilherme N
} Souza ${ }^{1,2,3^{*}}$

${ }^{1}$ Veterinary Medicine School, Federal Fluminense University, Niterói, RJ, Brazil

${ }^{2}$ Embrapa Dairy Cattle, Juiz de Fora, MG, Brazil

${ }^{3}$ Department of Science and Technology of Dairy, Juiz de Fora Federal University, Juiz de Fora, MG, Brazil

\begin{abstract}
The aim of this study was to evaluate the reduction of intramammary infection caused by Streptococcus agalactiae and Staphylococcus aureus in a Holstein dairy herd under tropical conditions. The period of study was from January 2012 from January 2013 in a dairy herd composed by Holstein cows, with an average of 142 lactating cows/month. Milk samples were collected from individual lactating cows for microbiological tests. The sampling lactating cows was in order to identify those infected by Streptococcus agalactiae for the treatment of all mammary quarters with intramammary antibiotics, as well as to identify chronically infected lactating cows by $S$. aureus for possible culling. During this period, 161 treatments of cows with an intramammary antibiotic were performed to eliminate Streptococcus agalactiae, and nine cows chronically infected with Staphylococcus aureus were culled. The percentages of infected cows with S. agalactiae in January 2012 and January 2013 were $61.6 \%$ and $2.2 \%$, respectively. For the same months, the percentages of cows infected with $S$. aureus were $28.3 \%$ and $19.4 \%$, respectively. The intramammary antibiotic treatment of lactating cows was efficient in eliminating infection caused by $S$. agalactiae and consequently the prevalence of infected animals in the herd. The reduction in $S$. aureus prevalence among cows was associated with the culling of cows chronically infected by this pathogen.
\end{abstract}

Keywords: Bovine mastitis; Microbiological diagnosis; Intramammary treatment; Staphylococcus aureus; Streptococcus agalactiae

\section{Introduction}

Streptococcus agalactiae and Staphylococcus aureus are contagious pathogens and are considered the major mastitis pathogens, because of their large effect on milk quality, production, and cow somatic cell count (SCC) [1]. The primary method to spread this pathogens is cow to cow, so the focus of prevention should be to reduce or eliminate herd infection [1]. In herds where the pattern of subclinical mastitis infection is by these contagious pathogens, the eradication of $S$. agalactiae and control and prevention of $S$. aureus must be the objectives. For $S$. agalactiae, eradication can be completed rapidly through a culture and treatment program with minimal culling. For S. aureus, treatment success, particularly during lactation, is often disappointing and depends on cow, pathogen, and treatment factors [1]. This way, the culling of animals with chronic infection by $S$. aureus is the most indicated strategy. Therefore, the microbiological diagnosis of mastitis is fundamental for the adoption of specific control measures, segregation and culling of animals with chronic infection, evaluation of treatment efficacy and establishment of antimicrobial susceptibility patterns [2]. The objective of this study was to assess the treatment with intramammary antibiotic and culling on a Holstein dairy herd in the process of Staphylococcus aureus and Streptococcus agalactiae control under tropical conditions.

\section{Materials and Methods}

The study was conducted in a dairy cattle herd located in the Zona da Mata, Minas Gerais, Brazil. The herd belongs to the Holstein Cattle Association of Minas Gerais State which has 112 herds. These herds have some common characteristics that are: breed, nutritional and reproductive management, milking machine and keep records on the productive, economic and mammary gland health indices. The studied herd was composed of Holstein cows, with an average of 142 lactating cows $/$ month and a mean production of $8,050 \mathrm{~kg}$ of milk over 305 days of lactation. The lactating cows were subjected to official milk production control through a monthly assessment of milk production and collection of milk samples to determine the composition (fat, protein, lactose and total solids) and somatic cells count (SCC). Milk samples from the herd (bulk tank) and cows were collected directly into vials containing preservative (Bronopol', D\&F Control Systems Inc.) for SCC. SCC was performed in the Milk Quality Laboratory of Embrapa Dairy Cattle in an automated flow cytometer (Somacount 300, Bentley Instruments Inc.) [3].

During the period from January 2012 to January 2013, milk samples were collected from individual lactating cows for microbiological tests. These samples were collected during the months of January $(n=159)$, February ( $\mathrm{n}=144)$, March ( $\mathrm{n}=131)$, April $(\mathrm{n}=146)$, May $(\mathrm{n}=157)$, August $(\mathrm{n}=149)$ and November $(\mathrm{n}=147)$ in 2012 and January $(\mathrm{n}=134)$ in 2013. The milk samples were taken from all lactating animals, excluding those who presented clinical mastitis at the time of collection or were being treated with antibiotics. The sampling of only lactating cows was in order to identify those infected by Streptococcus agalactiae for the treatment of all mammary quarters with intramammary antibiotics, as well as to identify chronically infected lactating cows by $S$. aureus for possible culling. The intramammary antibiotic used in cows infected by $S$. agalactiae were

*Corresponding author: Guilherme N Souza, Embrapa Dairy Cattle, Juiz de Fora, MG, Brazil, Tel: +55(32)33117405; Fax: +55(32)33117401; E-mail: guilherme.souza@embrapa.br

Received December 11, 2017; Accepted December 19, 2017; Published January 03, 2018

Citation: Mendonça JFM, Brito MAVP, Lange CC, Silva MR, Ribeiro JB, et al (2018) Prevalence Reduction of Contagious Mastitis Pathogens in a Holstein Dairy Herd Under Tropical Conditions. J Vet Sci Technol 9: 497. doi: 10.4172/2157. 7579.1000497

Copyright: (c) 2018 Mendonça JFM, et al. This is an open-access article distributed under the terms of the Creative Commons Attribution License, which permits unrestricted use, distribution, and reproduction in any medium, provided the original author and source are credited. 
cloxacillin (200 mg) and ampicillin (75 mg) (Bovigam L, Bayer SA) for three times at 12 hours intervals. A disposal milk period of 72 hours was adopted according to the manufacturer's recommendation. Cows with more than two successive $S$. aureus isolations were selected for culling. The prevalence estimate of $S$. agalactiae and $S$. aureus among lactating cows was calculated dividing the number of cows infected by each pathogen by total number of lactating cows with microbiological tests. The 95\% confidence interval (95\% CI) for prevalence was used to compare the prevalence of each pathogen according to months. Confidence intervals for prevalences in different months that did not present overlapping values were considered different $(\mathrm{P}<0.05)$. The $95 \%$ CI was estimated according to Pfeiffer (Equation 1), where "p" is the prevalence found and and " $n$ " is the total number of lactating cows with microbiological test for each month [4].

$$
95 \% C I=p \pm 1.96 \times \sqrt{\frac{p(1-p)}{n}}
$$

The milksample collection and transport procedures were conducted according to the National Mastitis Council guidelines (Laboratory and Harmon et al.) $[5,6]$. The mastitis-causing agents were identified in the Milk Microbiology Laboratory of Embrapa Dairy Cattle by seeding 0.01 $\mathrm{mL}$ of each milk sample in Petri dishes containing agar-blood prepared with $5 \%$ defibrinated lamb blood. The dishes were incubated at $37^{\circ} \mathrm{C}$ for 24 hours before the first reading was made, followed by incubation for an additional 24 hours for the second reading. The morphology and the number of isolated microorganism colonies were taken into consideration, and the results were interpreted according to the criteria proposed by the National Mastitis Council $[5,6]$. Biochemical tests were performed to confirm the pathogens agents of mastitis. Based on the microbiological and the biochemical test results, cows infected with $S$. agalactiae received three intramammary applications of antibiotic.

\section{Results}

The prevalences of infected cows with $S$. agalactiae in January 2012 and January 2013 were $61.6 \%$ and $2.2 \%$, respectively (Table 1). The lower prevalence $(0.7 \%)$ of $S$. agalactiae among lactating cows was observed on November, 2012, due to one cow infected. The $S$. agalactiae prevalence reduction was continuous from January 2012 to March 2012. After this period was observed an oscillation on prevalence ranging from $0.7 \%$ to $6.0 \%$.

The percentages of cows infected with $S$. aureus were $28.3 \%$ and $19.4 \%$ in January 2012 and January 2013, respectively. However, the prevalence of $S$. aureus increased from $28.3 \%$ to $38.9 \%$ from January 2012 to February 2012 (Table 1). The constant reduction of S. aureus prevalence was observed from May 2012 to January 2013, decreasing approximately $20 \%$ (Table 1 )
The impact on the reduction of the SCC values of the herd from $1,175,000$ cells $/ \mathrm{mL}$ to 899,000 cells $/ \mathrm{mL}$. Before intramammary antibiotic treatment the percentages of cows with values less than 200,000 cells $/ \mathrm{mL}$, between 200,000 and 400,000 cells $/ \mathrm{mL}$ and more than 400,000 cells $/ \mathrm{mL}$ were $85.5 \%, 12.0 \%$ and $2.5 \%$, respectively. The consequence of the treatment of cows infected with $S$. agalactiae was the reduction in the percentage of cows with SCCs above 400,000 cells/ $\mathrm{mL}$ from $67.9 \%$ to $56.5 \%$ and the increase in the percentage of cows with SCCs below 200,000 cells $/ \mathrm{mL}$ from $21.4 \%$ to $30.6 \%$. Notably, the mean milk production per cow over the 305 days of lactation increased from 17,115 to 17,725 pounds (approximately $7,763 \mathrm{~kg}$ to $8,040 \mathrm{~kg}$ ) during the period considered.

\section{Discussion}

The consequence of the treatment of cows infected with $S$. agalactiae was the reduction of approximately $60 \%$ in the prevalence of infected cows over time. The intramammary antibiotic treatment of lactating cows infected by $S$. agalactiae was performed after results of microbiological tests. The reduction of $S$. agalactiae prevalence was due to 161 intramammary antibiotic treatments of lactating cows infected with $S$. agalactiae during the studied period. A successive reduction in the prevalence of cows infected by $S$. agalactiae during the first three months of the study (January to March 2012) was observed, justified by the intramammary treatments applied on animals identified as positive for this pathogen. From that time, the prevalence of $S$. agalactiae in the herd remained statistically constant until the end of the study, probably because the results of microbiological tests were provided about 5 to 7 days after collected milk samples. The time between the collection of the milk samples and the results of the microbiological tests can be associated with oscillation of the prevalence of $S$. agalactiae among lactating cows because during this period cows infected were not treated and were source of infection to cows without infection. $S$. agalactiae is an obligate pathogen of the bovine mammary gland and rapid and successful eradication of this microorganism of the herd is achieved through the intramammary treatment of infected cows [1]. A study on contagious pathogens of mastitis was carried out in the herds of the Holstein Cattle Association of Minas Gerais State and a prevalence of $40 \%$ was observed for S. agalactiae among the herds [7]. The high prevalence $S$. agalactiae in these herds suggests that the control and prevention measures have not been adopted effectively [7]

The reduction of $S$. aureus prevalence was about $10 \%$ during the studied period. However, an increase of about $10 \%$ in the prevalence of S. aureus from January to February 2012 was observed. This increase was due to 19 cows that presented negative results for $S$. aureus and positive results to S. agalactiae in the first microbiological tests (January 2012) and after the intramammary antibiotic treatment presented positive

\begin{tabular}{|c|c|c|c|c|c|c|c|}
\hline \multirow{3}{*}{ Month/Year } & \multirow{3}{*}{ Number of lactating cows } & \multicolumn{6}{|c|}{ Microbiological test } \\
\hline & & \multicolumn{3}{|c|}{ Staphylococcus aureus } & \multicolumn{3}{|c|}{ Streptococcus agalactiae } \\
\hline & & $\mathbf{n}$ & $\mathbf{P}$ & $\mathrm{Cl} 95 \%$ & $\mathbf{n}$ & $\mathbf{P}$ & $\mathrm{Cl} 95 \%$ \\
\hline Jan-12 & 159 & 45 & 28.3 & $21.3-35.3^{\mathrm{ab}}$ & 98 & 61.6 & $54.1-69.2^{\mathrm{a}}$ \\
\hline Feb-12 & 144 & 56 & 38.9 & $30.9-46.9^{a}$ & 27 & 18.8 & $12.4-25.1^{\mathrm{b}}$ \\
\hline Mar-12 & 131 & 39 & 29.8 & $21.9-37.6^{\mathrm{ab}}$ & 5 & 3.8 & $0.5-7.1^{c}$ \\
\hline Apr-12 & 146 & 49 & 33.6 & $25.9-41.2^{\mathrm{ab}}$ & 7 & 4.8 & $1.3-8.3^{c}$ \\
\hline May-12 & 157 & 55 & 35 & $27.6-42.5^{\mathrm{ab}}$ & 6 & 3.8 & $0.8-6.8^{c}$ \\
\hline Aug-12 & 149 & 52 & 34.9 & $27.2-42.6^{\mathrm{ab}}$ & 9 & 6 & $2.2-9.9^{c}$ \\
\hline Nov-12 & 147 & 45 & 30.6 & $23.2-38.1^{\mathrm{ab}}$ & 1 & 0.7 & $0,0-2,0^{c}$ \\
\hline Jan-13 & 134 & 26 & 19.4 & $12.7-26.1^{b}$ & 3 & 2.2 & $0,0-4.7^{c}$ \\
\hline
\end{tabular}

Table 1: Results of microbiological test and prevalence according to mastitis contagious pathogens in one dairy herd from January 2012 to January 2013. 
Citation: Mendonça JFM, Brito MAVP, Lange CC, Silva MR, Ribeiro JB, et al. (2018) Prevalence Reduction of Contagious Mastitis Pathogens in a Holstein Dairy Herd Under Tropical Conditions. J Vet Sci Technol 9: 497. doi: 10.4172/2157-7579.1000497

results for $S$. aureus and negative results for $S$. agalactiae in the second microbiological test (February 2012). The intramammary antibiotic treatment eliminated the infection caused by $S$. agalactiae and allowed in the next microbiological test to identify cows infected by $S$. aureus. The $S$. aureus prevalence presented oscillation from January 2012 to April 2012, from $28.3 \%$ to $33.6 \%$, respectively. A significant reduction $(\mathrm{P}<0.05)$ in the prevalence was observed from February 2012 to January 2013 , reaching a reduction about 20\%. However, from January 2012 to November 2012 was not observed difference between prevalence in this period (Table 1). This reduction can be associated with culling of nine cows with chronic infection by $S$. aureus. The culling of chronically infected cows is the main indicated strategy to control and prevention of the infection by this pathogen in the herd [1]. The success in treatment of infected animals is more difficult because $S$. aureus is an intracellular pathogen and predisposal to abscesses formation [1].

The reduction of bulk tank somatic cell counts was probably due to a reduction in the percentage of animals infected with both pathogens. Well management herds should have a prevalence of chronic infections (individual cows repeatedly higher than 200,000 cells $/ \mathrm{mL}$ ) of less than $5 \%$, and the incidence of new intramammary infections (cows breaching a 200,000 threshold) of less than $5 \%$ on a monthly basis [1] and percentage of cows above somatic cell count cur-off limit $(200,000$ cells $/ \mathrm{mL}$ ) less than $20 \%$ [8]. According to Philpot and Nickerson, cows with SCCs above 400,000 cells $/ \mathrm{mL}$ reduce their milk production from 1,188 to 1,980 pounds (approximately 538 to $898 \mathrm{~kg}$ ) per lactation [9]. Cunha et al. confirmed this information in Brazil; in that study, Holstein animals raised in tropical conditions had less milk production as the SCC increased [10]. This increase in production may be due to a reduction in the percentage of cows infected with contagious mastitis pathogens, especially $S$. agalactiae, compared to the reduction of cows infected with $S$. aureus.

\section{Conclusions}

The intramammary antibiotic treatment of lactating cows was efficient in eliminating infection caused by $S$. agalactiae and consequently reducing the prevalence of infected animals in the herd. However, the same efficiency of intramammary antibiotic treatment in eliminating $S$. agalactiae infection was not observed for $S$. aureus. The reduction in $S$. aureus prevalence among cows was associated with the culling of cows chronically infected cows by this pathogen. The intramammary antibiotic treatment of cows infected with $S$. agalactiae and the culling of cows chronically infected by $S$. aureus was associated with a reduction in the SCC of the cows and herd (bulk tank) and with an increase in milk production at 305 days of lactation.

\section{Acknowledgements}

Fundação de Amparo à Pesquisa do Estado de Minas Gerais (FAPEMIG APQ CVZ 01637/2014) for financial support. Associação dos Criadores de Gado Holandês de Minas Gerais (ACGHMG) by official reports of milk control program of Santa Maria Farm. Santa Maria farm for giving the somatic cell counts reports.

\section{References}

1. Keefe GP (2012) Update on control of Staphylococcus aureus and Streptococcus agalactiae for management of mastitis. Vet Clin North Am Food Anim Pract 28: 203-216.

2. Brito MAVP (2008) Importância do diagnóstico microbiológico para a detecção da mastite. In: Barbosa SBP, Batista AMV, Monardes H (eds.), III Congresso Brasileiro de Qualidade do Leite. Recife: CCS Gráfica e Editora 1: 145-160.

3. International Dairy Federation (1995) Milk enumeration of somatic cells Brussels: IDF Standard, p: 8.

4. Pfeiffer D (2010) Veterinary Epidemiology: An introduction. John Wiley \& Sons Ltd, p: 135.

5. Barnes-Pallesen FD, Blackmer $P$, Britten A, Bushnell RB, Van Damme DM et al. (1987) Laboratory and field handbook on bovine mastitis. Natl Mastitis Counc, Arlington, p: 208

6. Harmon RJ, Eberhart RJ, Jasper DE (1990) Microbiological procedures for the diagnosis of bovine udder infection and determination of milk quality. Natl Mastitis Counc, Arlington, p: 34

7. Oliveira EF, Brito MAVP, Lange CC, Hylario SM, Bruno AF, et al. (2013) Estimate of Staphylococcus aureus and Streptococcus agalactiae prevalence among dairy herds from Minas Gerais Holstein Dairy Association, Brazil, 2011/2012. In: 52 Natl Mastitis Counc Annual Meeting, San Diego, USA, pp: 209-210.

8. Schukken YH, Kremer DJ (1996) Part 1: Monitoring udder health: objectives materials and methods. In: Brand A, Noordhuizen JPTM, Schukken YH (eds.) Herd health and production management in dairy practice. Wageningen: Wageningen Pers, pp: 351-360

9. Philpot WN, Nickerson SC (1991) Mastitis: counter attack. Babson Bros Co. p: 150.

10. Cunha RPL, Gentilini MB, Ferreira PM, Facury Filho EJ, Carvalho AU, et al. (2008) Subclinical mastitis and somatic cell count relationship with number of lactations, milk yield and chemical composition in Holstein cows. Arq Bras Med Vet Zootec 60: 19-24. 